\title{
The inheritance and gift tax in Germany: Reform potentials for tax revenue, efficiency and distribution
}

\author{
MARTIN BEZNOSKA, Dr.* \\ TOBIAS HENTZE, Dr.* \\ MAXIMILIAN STOCKHAUSEN, Dr.*
}

Article**

JEL: D31, H20

https://doi.org/10.3326/pse.44.3.5

\footnotetext{
* The authors would like to thank the two anonymous referees, Hrvoje Šimović, the participants of the conference Public Sector Economics, October 242019 in Zagreb, Andreas Thiemann, and the participants of the in-depth session Inheritance and gift tax in Germany, October 162019 in Brussels organised by the European Commission for useful comments and suggestions.

${ }^{* *}$ Received: November 6, 2019

Accepted: May 13, 2020
}

\section{Martin BEZNOSKA}

German Economic Institute, Postfach 1019 42, 50459 Köln, Germany e-mail: beznoska@iwkoeln.de

ORCiD: 0000-0002-9966-221X

\section{Tobias HENTZE}

German Economic Institute, Postfach 1019 42, 50459 Köln, Germany

e-mail: hentze@iwkoeln.de

ORCiD: 0000-0003-0900-8554

Maximilian STOCKHAUSEN

German Economic Institute, Postfach 1019 42, 50459 Köln, Germany

e-mail: stockhausen@iwkoeln.de

ORCiD: 0000-0002-6340-6142 
Abstract:

The inheritance tax is often seen as an effective tool to reduce wealth inequality, to raise public revenues if needed, and to increase incentives to work by lowering the tax burden on labour, which is especially high in Germany, according to the OECD. The purpose of this paper is therefore to shed light on the question of whether an inheritance tax is a promising tool for fighting wealth inequality without having distorting effects on the economy. For this purpose, firstly, the distributional effects of inheritances on wealth distribution are evaluated for Germany and are then compared with those in Austria and France, using data from the Household Finance and Consumption Survey (HFCS). A change in the German inheritance tax law in 2009 is further used in a difference-in-difference analysis to identify the behavioural effects of the change in the inheritance tax on the volume of bequests, which are large and robust for different specifications. Secondly, the insight from part one is applied to the design of an inheritance tax reform for Germany. The potential tax revenue of the reform can be estimated by using the data from the inheritance and gift tax statistics. A revenue shift from income to inheritance tax could be used to increase work incentives by cutting the marginal tax rates for the working population. However, it turns out that taxing inheritances will be accompanied by significant behavioural responses of donors via tax planning. Furthermore, the introduction of a flat tax model with a broad tax base would not generate enough additional revenue to foster relevant employment effects.

Keywords: inheritance taxation, wealth distribution, redistribution, inequality, labour supply, Germany

\section{INTRODUCTION}

In 2013, Thomas Piketty's book "Capital in the Twenty-First Century" led to a surge in the public debate on inequality. He argued, amongst other things, that inheritances play an important role in explaining the inequality of wealth distribution (Piketty, 2013). Against this background, taxing wealth and inheritances to a larger extent is back on the table. Piketty, for example, estimates an inheritance tax rate between 50 percent and 60 percent as optimal regarding the equity-efficiency trade-off for the United States and France (Piketty and Saez, 2013). Equity and efficiency are the two central principles in tax policy. Proponents of the inheritance and gift tax - referred to below as inheritance tax - emphasize its potential power to fight wealth inequality (Beckert and Arndt, 2016). According to the OECD (2018), from both an efficiency and an equity perspective, inheritance taxes are a feasible tool in tax policy and are a better alternative to taxes on net wealth. In contrast to a net wealth tax, the complex valuation of assets usually takes place only once per generation instead of annually and, thus, raising the tax is less costly. In addition, inheritance taxes tend to be less distortive.

Inheritance taxes are of great interest for another reason: It is widely supposed that the volume of inheritances will continue to grow due to demographic changes. 
The volume of taxable inheritance has more than doubled in the past decade. Higher revenue from the inheritance tax might increase the incentives to work, by lowering the tax burden on labour, which is particularly high in Germany according to the OECD (2019: 147). The International Monetary Fund (IMF, 2019) proposes a tax reform for Germany consisting of two pillars: First, the tax wedge on labour should be decreased. Second, inheritance and property taxes should be used to satisfy any fiscal needs.

Historically, the inheritance tax in Germany has repeatedly been subject to decisions by the constitutional court regarding discrimination issues. Substantial and long-lasting reforms have often been claimed. Currently, the inheritance tax law is characterized on the one hand by high and progressive tax rates of up to 50 percent and, on the other hand, by remarkable personal tax allowances as well as tax exemptions for business assets. This limits the effective tax rate on inheritances and leads to a revenue proportion of less than 1 percent in terms of total tax revenue. The repeated court decisions indicate that the political will in Germany for any reform has not been very high.

This is understandable since cutting the personal tax allowances would most likely not be accepted by voters. According to a representative survey, three out of four Germans are in favour of the higher taxation of inheritances exceeding 1 million euro per heir (Deutsche Bank, 2018: 57). This implies that, for example, a tax-free bequest of a private real estate ("grandma's house") should be ensured. Furthermore, the taxation of inheritances comes at a cost, since optimal decisions for consumption and capital accumulation of testators are distorted. This is especially risky in the case of inherited company shares as business continuity could be threatened, which in consequence can increase unemployment. This would widen of the gaps in wealth inequality in the long run, since the unemployed cannot save at all. Therefore, any reform of the inheritance tax is a complex matter. A well-designed tax law is needed to achieve a high degree of equity and efficiency.

\section{INHERITANCE TAX IN GERMANY}

Even if the inheritance tax plays an important role in public debates, it is of minor importance from a fiscal perspective. In all OECD countries the revenue it produces accounts for less than 1 percent of total tax revenue (including social security contributions). In Germany, the fiscal importance of the inheritance tax is above the OECD average at below 0.2 percent of GDP (Figure 1). Only in Belgium, France, Finland, Korea and Japan is the relevance of the inheritance tax significantly greater than in Germany. Eleven OECD countries do not levy an inheritance tax at all. 


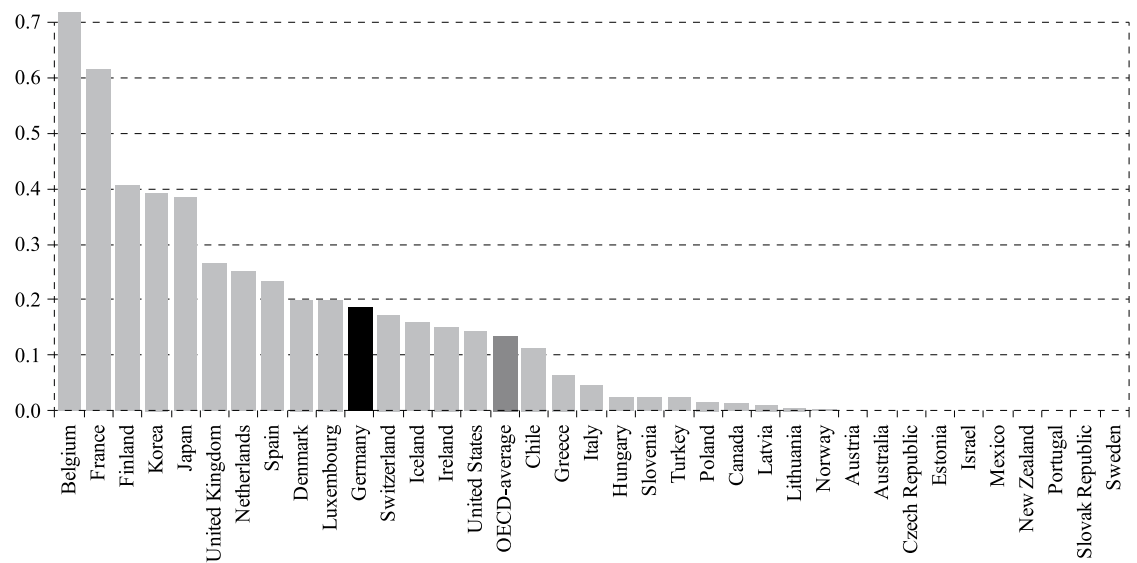

Note: OECD statistics total tax revenue include social security contributions and therefore differ from national statistics. The value for Greece refers to 2016.

Source: OECD database, own illustration.

The inheritance tax has been of minor fiscal importance in Germany for decades. In the beginning of the $1960 \mathrm{~s}$ and $1970 \mathrm{~s}$, it contributed on average only 0.3 percent to the total tax revenue (without social security contributions). In the 1980s and $1990 \mathrm{~s}$, the value went up slightly. The uptick continued, reaching an all-time maximum in 2016 of almost 1 percent. In 2018, while total tax revenue in Germany amounted to nearly 780 billion euro, the revenue from the inheritance tax only amounted 6.7 billion euro, which is about 0.8 percent.

A long-term trend for the fiscal importance of the inheritance tax to increase can be seen in Figure 2. Its overall growth since 1991 is remarkably higher than that of total tax revenue. Some of these increases may be due to demographic changes, which are expected to foster wealth concentration and bequest volume in the future (Zagheni and Wagner, 2015). But another reason may be the great fluctuation of the tax base via tax planning of donors and testators in response to tax reforms (Sommer, 2017). The appearance of the latter phenomenon will be examined in the following chapters. 


\section{Figure 2}

Inheritance tax and total tax revenue in Germany, Index: 1991=100 (in \%)

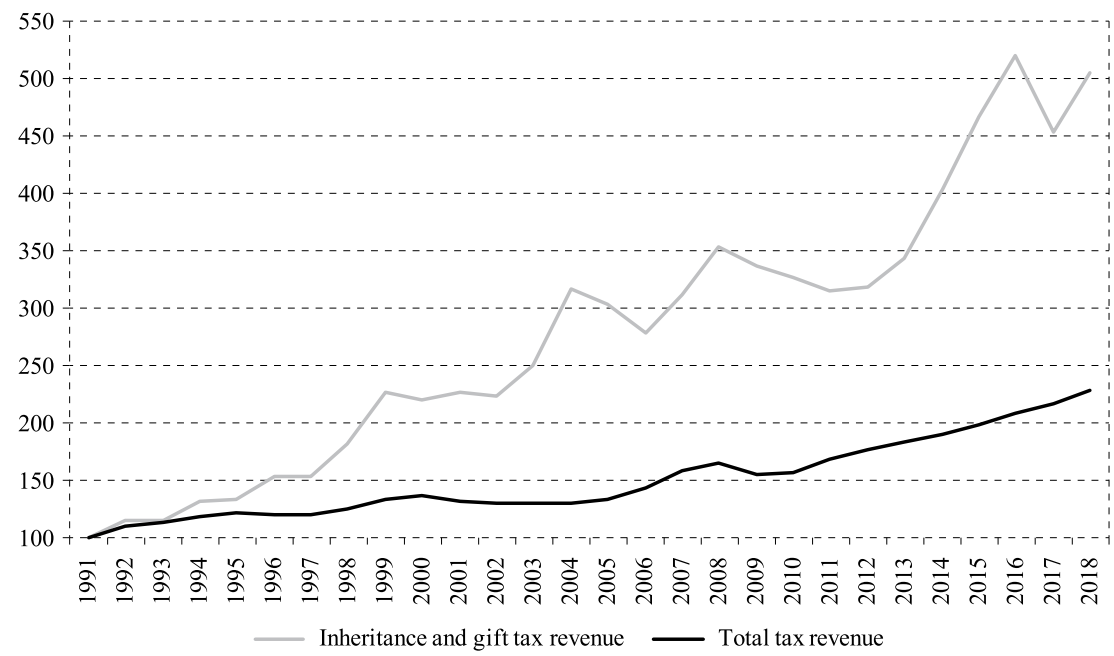

Source: Bundesministerium der Finanzen, 2019; own calculations.

In Germany, the inheritance tax has always been levied on the inheritor. In contrast, in the United States, the whole inheritance is taxed at once and the inheritance tax must be paid by the testator. This difference in tax design implies that the tax base in Germany is often significantly smaller than the value of the inheritance as it is divided by the number of inheritors.

The nominal tax rates are progressive and depend on the value of the inheritance as well as on the tax class (Table 1). The three tax classes are defined by the degree of relationship (Table 2). The minimum tax rate is equal to 7 percent, while the maximum is 50 percent.

\section{TABLE 1}

Inheritance tax rates (in \%)

\begin{tabular}{|c|c|c|c|}
\hline $\begin{array}{l}\text { Tax bracket in euro } \\
\text { up to thousands }\end{array}$ & Tax class I & Tax class II & Tax class III \\
\hline 75 & 7 & 15 & 30 \\
\hline 300 & 11 & 20 & 30 \\
\hline 600 & 15 & 25 & 30 \\
\hline 6,000 & 19 & 30 & 30 \\
\hline 13,000 & 23 & 35 & 50 \\
\hline 26,000 & 27 & 40 & 50 \\
\hline above 26,000 & 30 & 43 & 50 \\
\hline
\end{tabular}

Source: German inheritance tax and gift tax law, own illustration.

Up to 2008, Germany imposed an inheritance tax with a general tax allowance for the business sector combined with a valuation method for business assets that was 
not intended to reflect market value and, thus, led to rather small values. As family-owned companies play a significant role in the German economy, taxing the substance of a family business in the case of succession means a competitive disadvantage for this company. This can limit future investments or even put existing jobs at risk. However, the Federal constitutional court challenged these rules. The inheritance tax had to be renewed since the assessed tax values did not reflect the actual value (BVerfG, 2006). The valuation for the relevant asset categories differed significantly. Hence, the tax rules and tax exemptions were modified in Germany by changing the valuation rules as well as increasing tax allowances and exemptions for businesses.

\section{TABle 2}

Personal tax allowances (in thousand euro) and tax classes

\begin{tabular}{|c|c|c|}
\hline & $\begin{array}{l}\text { Personal tax } \\
\text { allowance } \\
(\$ 16 \text { Inheritance } \\
\text { tax law })\end{array}$ & $\begin{array}{c}\text { Tax class } \\
(\$ 15 \text { Inheritance } \\
\text { tax law })\end{array}$ \\
\hline $\begin{array}{l}\text { For spouse and partner of a registered civil } \\
\text { partnership }\end{array}$ & 500 & $\mathrm{I}$ \\
\hline $\begin{array}{l}\text { For children and grandchildren whose parents } \\
\text { have died, as well as for stepchildren and } \\
\text { adopted children }\end{array}$ & 400 & I \\
\hline For grandchildren & 200 & I \\
\hline $\begin{array}{l}\text { For great-grandchildren; for parents } \\
\text { and grandparents to acquire by inheritance }\end{array}$ & 100 & I \\
\hline $\begin{array}{l}\text { For parents and grandparents in the case } \\
\text { of gift, for siblings, children of siblings, } \\
\text { stepparents, children in law, parents-in-law, } \\
\text { divorced spouses and life partner of a cancelled } \\
\text { civil partnership }\end{array}$ & 20 & II \\
\hline For all other recipients of a gift or inheritance & 20 & III \\
\hline
\end{tabular}

Source: German inheritance tax and gift tax law, own illustration.

Nonetheless, the new rules were challenged again by the Federal Constitutional Court in 2014 since the extent of tax exemptions introduced by the previous reform was not justified. The law had to be renewed by June 30, 2016. However, the general approach of tax exemptions for the business sector was not challenged. The judgement consisted of three pillars.

Firstly, even the heirs of small businesses must demonstrate a commitment to retain jobs to obtain exemption from the tax. Companies with up to 20 employees were excluded from these requirements before. The maximum number of employees is now set to five in order not to generally exclude too high a share of companies from the tax. However, if heirs sell the company shares within a few years, they will lose the tax exemption. 
Second, what are called administrative assets, including non-business assets such as pieces of art or leased land, were no longer spared as generously as in the past. The maximum ratio of administrative assets to operating assets has been decreased from 50 percent to 10 percent. Those administrative assets exceeding the percentage rate are fully taxed.

Third, the heirs of large companies or company shares will not be able to avoid the statutory tax rate anymore, unless they can prove that they have no financial abilityto-pay. The constitutional court has criticized the exemption of large corporate heirs regardless of their economic situation and solvency. For this reason, the federal government has set a threshold of 26 million euro in terms of inheritance value per heir. Above this threshold, the full inheritance value without any tax exemptions is taxed unless the heir has no ability-to-pay. This means that the heir must use up to 50 percent of own total assets to pay the bill. If the heir does not want to disclose the value of private assets, the heir can accept a smaller tax exemption declining with the value of the inheritance (Beznoska and Hentze, 2016).

In the context of the reform, the valuation parameters for business assets were corrected in order to eliminate any overvaluation. In 2015, the overvaluation of business assets was about 50 to 60 percent (Hentze, 2016). The magnitude is (hypothetically) confirmed by today's (2019) parameters, assuming the previous tax law to be still effective (Table 3). A value of 44 percent in calculation (3) means an overvaluation of 56 percent. Due to the adjustment of the valuation parameters as part of the inheritance tax reform in 2016, the overvaluation of business assets declined to approximately 11 percent (market value is equal to 89 percent of the current tax law value, see Table 3 ).

\section{TABLE 3}

\section{Valuation of business assets}

\begin{tabular}{|c|c|c|c|}
\hline & $\begin{array}{l}\text { Law before } \\
\text { the } 2016 \\
\text { reform }\end{array}$ & $\begin{array}{l}\text { Law after } \\
\text { the } 2016 \\
\text { reform }\end{array}$ & $\begin{array}{c}\text { Current } \\
\text { market } \\
\text { valuation }\end{array}$ \\
\hline Basic interest rate (in \%, 2019) & 0.6 & - & 0.6 \\
\hline Market risk premium (in \%) & 4.5 & - & 7.0 \\
\hline Beta factor & 1 & - & 1 \\
\hline Capitalization rate (in \%) & 5.1 & - & 7.6 \\
\hline $\begin{array}{l}\text { Capitalization factor } \\
\text { (1/capitalization rate) }\end{array}$ & 19.61 & 13.75 & 13.16 \\
\hline $\begin{array}{l}\text { Markdown due to limited fungibility } \\
\text { of family owned companies (in \%) }\end{array}$ & - & 30 & 35 \\
\hline Adjusted capitalization factor & 19.61 & 9.63 & 8.55 \\
\hline In percent of (1) & & & 44 \\
\hline In percent of (2) & & & 89 \\
\hline
\end{tabular}

Note: Current market valuation compared to the rule of law before and after the reform in 2016. Source: KPMG (2019); own calculations. 
The modified valuation parameters partly offset the restriction of tax exemptions regarding the tax liability of inherited business assets. Generally, the tax burden for large inheritances of companies has increased due to the reform in 2016 while it can be lower for smaller ones (Beznoska and Hentze, 2016).

\section{INHERITANCES AND NET WEALTH INEQUALITY}

How inheritances shape wealth distribution and what behavioural effects are associated with a change in the inheritance tax on the volume of bequests is the subject of the following chapter. In particular, the effects of inheritances on net wealth distribution are discussed in a comparative framework using survey data for Germany, Austria, and France from the Household Finance and Consumption Survey (HFCS). The descriptive analysis is extended by a comprehensive difference-in-difference analysis exploiting the differences between Germany and France to identify the behavioural effect of the change in the German inheritance tax law in 2008 on the volume of bequests.

\subsection{DISTRIBUTIONAL EFFECTS OF INHERITANCES ON NET WEALTH INEQUALITY}

As we know from previous research, inheritances are crucial for the relative net wealth position of private households and they are unequally distributed among them. About one third of all European households have inherited wealth - the share is also one third in Germany - and these households are on average wealthier than those without any bequests (Fessler and Schürz, 2015). In addition, the International Monetary Fund states that inheritances of family businesses in particular contribute to a large extent to the gap between wealthy and non-wealthy households (IMF, 2019). Company shares are mainly owned by a rather small number of households. Therefore, wealth in terms of family businesses is highly concentrated. However, even if the importance of family businesses for the German economy were lower and the share of stockholders higher, it is unclear whether the resulting wealth concentration would be significantly lower in the long run because the stockholder allocation could still tend to be very unequal among German households. In addition, the low share of people owning stocks in Germany today gives us reason also to expect a rather unequal distribution of stocks in this alternative state of the world while a large fraction of company stocks could also be owned by foreign shareholders, which would reduce the equalizing effect among German households.

A common belief is that unequally distributed inheritances increase wealth inequality and, thus, should be taxed heavily. But inheritances have two distinct effects. On the one hand, inheritances generally increase inequality within a generation (Brunner, 2014). On the other hand, inheritances redistribute wealth between generations and thus have an inequality-decreasing effect, too. In sum, the latter effect seems to outweigh the first, so that the overall effect of inheritances is inequality-decreasing (see Wolff and Gittleman, 2014; Bönke, Werder and Westermeier, 2017; Beznoska, Niehues and Stockhausen, 2018: 13). 
In this regard, Bönke, Werder and Westermeier (2017) show for a wide range of euro area countries that the coefficient of variation on overall net wealth including inheritances is always smaller than if the capitalized value of inheritances is subtracted from net wealth. The only exception is Luxembourg. For example, the coefficient of variation on net wealth including inheritances is 2.8 in Germany in 2010, while it is 7.1 if the capitalized value of inheritances is excluded from net wealth. The results for Austria and France are similar: The coefficient of variation on net wealth including inheritances is 2.9 in Austria and 3.6 in France. If the capitalized value of inheritances is excluded from net wealth, the coefficient of variation is 12.3 and 105.6 , respectively.

The same equalizing effect also persists if a different inequality measure is used for a more recent year, here the Gini coefficient in 2014. The data used for this are taken from the HFCS, first conducted in 2010 under the supervision of the European Central Bank (ECB). Data of the second wave, in 2014, have been used for our analyses. The third wave, covering the year 2017 , is not yet available. The HFCS provides harmonised household data for more than 84,000 households in 18 euro area countries except Lithuania. Hungary and Poland are also covered (ECB, 2016). A major advantage of the HFCS is its rich information on assets, liabilities, income and consumption of households in the eurozone. It also encompasses data on the time and value of the three most important inheritances and gifts inter vivos a household has ever received.

In Figure 3, Gini coefficients on capitalized bequests (assuming a real interest rate of 3 per cent on average), net wealth including capitalized bequests, and net wealth excluding capitalized bequests are depicted for Germany, Austria, and France in 2014. These three countries are well suited for comparison because of similarities with regard to the level of the welfare state as well as structural parameters of the economy. Three things stand out: 1) Capitalised inheritances are generally the most unequally distributed and France shows the highest degree of inequality of these three countries. 2) Net wealth excluding capitalised inheritances is more equally distributed than inheritances. 3) The most equally distributed is net wealth including capitalized bequests. Thus, the combination of two unequal distributions leads to a third, more equal distribution. This effect can be observed in all three countries under consideration. This mainly results from the facts that the relative importance of the value of inheritances decreases with an increase of the wealth position and that inheritances are usually divided among several heirs. Or as Bönke, Werder and Westermeier (2017) put it: "in relative terms - poorer households tend to receive higher inheritances", which reduces overall relative net wealth inequality. 


\section{Figure 3}

Gini coefficients for different wealth types in Germany, Austria, and France (2014)

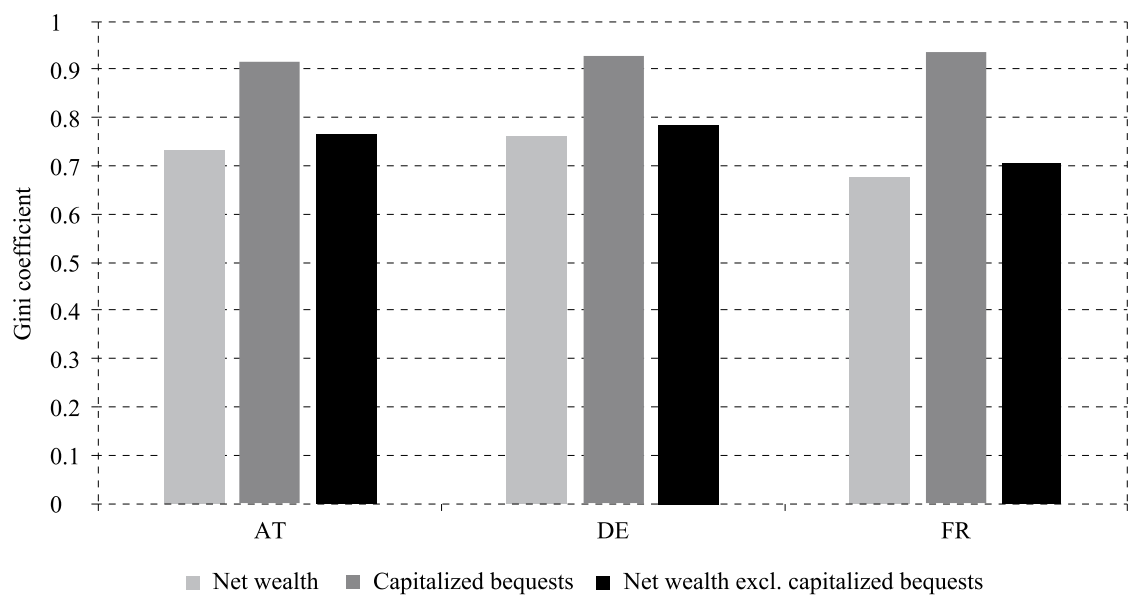

Note: A real interest rate of $3 \%$ per annum is used for capitalisation since the year of transfer receipt. For this purpose, all bequests are expressed in prices of 2010 using country specific consumer price indices.

Source: ECB, 2nd wave; own calculations.

Similar equalizing effects are found in Boserup, Kopczuk and Kreiner (2016) for Denmark as well as in Elinder, Erixson and Waldenström (2018) for Sweden. Both studies exploit comprehensive administrative datasets to evaluate the effects of bequests on the level and distribution of net wealth. They also find that bequests increase absolute wealth inequality due to a higher variance of bequests among heirs, but they decrease measures of relative wealth inequality, since the relative importance of bequests is larger for households with no or little pre-bequest wealth.

The empirical literature on the direct effects of an inheritance tax on the distribution of net wealth is still very limited. One major reason for this is the lack of appropriate data in most countries. Since an inheritance tax includes allowances and gradually rising nominal tax rates in many countries, the tax is quasi-progressive by construction, so that the average nominal tax rate increases with increasing inheritance value. However, the effective tax rate can differ, for example, due to tax exemptions for business assets. The overall effect of the inheritance tax can thus be regressive.

It is not clear a priori whether the redistributive effect of inheritances shown above will increase or decrease as a result of a progressively designed inheritance tax. Ultimately, it depends on how exemptions are designed, who receives the inheritance, i.e. the position in the wealth distribution, and how the inheritance tax revenues are redistributed. Since inheritance tax revenues are rarely passed on to less wealthy households as a direct wealth transfer, taxation does not necessarily 
lead to a greater alignment of net wealth. If, for example, inheritance tax receipts are used to finance basic insurance benefits, this will equalise income flows, but not wealth stocks. At least not in the short term. In contrast, an inheritance or gift is a direct wealth transfer - in many cases between households - that directly effects the distribution of net wealth. Hence, even a 100 percent taxation of inheritances would not automatically lead to a decrease in net wealth inequality. The opposite could be the case.

Elinder, Erixson and Waldenström (2018) were the first to examine the (mechanical) effects of an inheritance tax on wealth inequality, using Swedish tax data. For this purpose, they calculate the difference of Gini coefficients for net wealth including inheritances net-of-inheritance-tax payments and including inheritances before tax payments. The behavioural responses of testators or heirs due to changes in inheritance taxation are not considered in their analysis. Their key finding is that taxing inheritances increases relative inequality (but reduces absolute dispersion), since the relative inheritance tax burden is larger for less wealthy households of heirs than for the wealthy. Hence, a (progressive) inheritance tax counteracts the equalizing inheritance effect, although the effects are small.

Unfortunately, the effect of the abolishment of the inheritance tax in Austria in 2008 on the distribution of net wealth cannot be observed and exploited for our analysis, since there is no comprehensive wealth data for the years before 2010 . However, at the very least, the abolition of the inheritance tax in Austria did not let wealth inequality rise in the following years. Between years 2010 and 2014 net wealth inequality - measured by the Gini coefficient - decreased and remained unchanged up to the year 2018 (Fessler, Lindner and Schürz, 2019). In Germany, net wealth inequality slightly increased from 2010 to 2014 but by 2018 had not changed very much (Deutsche Bundesbank, 2019).

\subsection{BEHAVIOURAL EFFECTS OF AN INHERITANCE TAX ON THE VOLUME OF BEQUESTS}

The rich information content of the HFCS can also be exploited to depict the development of the volume of inheritances over time in different countries. Nevertheless, we are aware of several limitations of the HFCS data regarding, for example, the representativeness of the very rich or issues of unit and item nonresponse, which are addressed by oversampling of the rich (the very top is still missing) or strategies of multiple imputations to generate missing information (Tiefensee and Grabka, 2016). These problems make it even more difficult to make reliable statements on the effects of an inheritance tax on individual behaviour and the volume of bequests. However, we shall endeavour to approach this question with cautious use of HFCS data, still the best available.

For this purpose, Germany, France, and Austria are investigated in more detail, again, since they all have undergone interesting changes in their inheritance tax laws in recent years. While taxation of inheritances was abolished in Austria at the 
beginning of 2008 (except for transfers of real estate), allowances were increased for all tax classes in Germany to January 1,2009 and tax brackets were unified and partly increased for distant relatives. Additionally, the general tax exemptions for business assets in Germany were replaced by new valuation rules combined with exemptions, which were more comprehensive than before. However, before exemptions were granted, considerable and complex demands were made on a business's ability to guarantee the retention of jobs (see chapter 2). The debate on the necessary changes to inheritance taxation in Germany was very intensive in 2007 and 2008 and the legislator delayed for the maximum allowable period before implementing the new regulations. As a result, there was uncertainty as to when the reform would be introduced and households seem to have changed their behaviour, particularly with regard to the planning of gifts already in 2008. This is the main reason why we already include 2008 in the first period after the reform in a difference-in-difference analysis. As a robustness check we will change this and exclude 2008 from the first period after the reform. In France, the inheritance tax was completely abolished for spouses in 2008 and higher allowances were granted in 2012.

Figure 4 depicts the descriptive analysis of the volume of inheritances for five periods of a similar length; three periods before and two after the inheritance tax reform in Germany, namely 1996-1999, 2000-2003, 2004-2007, 2008-2011, and 2012-2014. The last period encompasses only three years instead of four. That is why the yearly period averages are also depicted in Figure 4 (right scale) next to the period totals (left scale). In general, we find that the inheritance volume measured in 2010 prices increased in all three countries during the first three periods. The increase is less pronounced in Austria. The trend changes in the fourth period: in Germany, the inheritance volume more than halves and decreases from 304 billion euro in period three to 135 billion euro in period four. In France, it continues to increase and reaches a new high of 202 billion euro. In Austria, the inheritance volume increases from 25 to 34 billion euro.

What are the probable reasons for the different developments? The decrease in Germany can be the result of higher inheritance tax rates for distant relatives combined with some pull-forward effects that took place before the introduction of the reform and are due to uncertainty about the future. A large source of uncertainty in this period can especially stem from the new rules regarding business assets, which introduced a lot of complexity into the inheritance tax law. Higher tax allowances for spouses/partners should have counteracting effects, but they seem to be less strong. This might also be due to the data structure of the HFCS which only covers inheritances among households while in most cases beneficiary spouses live in the same household. The abolition of the inheritance tax for spouses in France in 2008 should therefore have a positive effect that is also not covered well in the HFCS data. For our difference-in-difference estimator this is good news because it helps us to clearly identify the effect of the German inheritance tax reform on the level of bequests. The increase in Austria is as expected, reflecting the complete abolition 
of the inheritance tax in 2008. The effects of the Great Recession in 2007/2008 seem to be of less importance regarding the trends in inheritance volumes and should have affected the three countries in a similar way.

The development from the fourth to the fifth period is also different in each country. In Germany, the volume of inheritance increases and continues to increase with the same speed as before the reform in 2008. The yearly period average in period five is even slightly higher than in the third period. In France, the volume of inheritances does not change between the fourth and fifth period regarding the yearly period averages. This is as expected since there was another inheritance tax reform in 2012 in which allowances for close relatives were decreased. In contrast, there was a decrease of the mean volume of inheritances in Austria from the fourth to the fifth period. This may be induced by pull-forward effects that took place in the period of the abolishment of the inheritance tax. Overall, the descriptive analysis shows that even minor changes in inheritance taxation are accompanied by a considerable change in inheritance tax volumes as we would expect them from theory.

Next, a difference-in-difference estimator is applied to Germany and France to identify the differential effects of the inheritance tax changes in Germany in 2008 on the volume of bequests. For this purpose, country differences between Germany and France are exploited and exogeneous variation is created by the inheritance changes in Germany where allowances were increased across all tax classes on the one hand and where tax brackets were unified and mostly increased for distant relatives.

A critical assumption for the validity of the difference-in-difference estimator is that the development of the inheritance volume must have been similar in both countries before the treatment (but not in the levels). If the common trend assumption is violated then the difference-in-difference estimator would be biased (Ashenfelter, 1978; Ashenfelter and Card, 1985; Card and Krueger, 1994; Meyer, 1995; Bertrand, Duflo and Mullainathan, 2004; Schmitz, 2019, among others). Our graphical analysis in Figure 4 gives evidence that the common trend assumption holds for Germany and France before the treatment happened. Austria is therefore not used in this setting, since it is expected to violate the common trend assumption of the difference-in-difference estimator to get unbiased results. 


\section{Figure 4}

\section{Inheritance volume in Germany, Austria, and France}
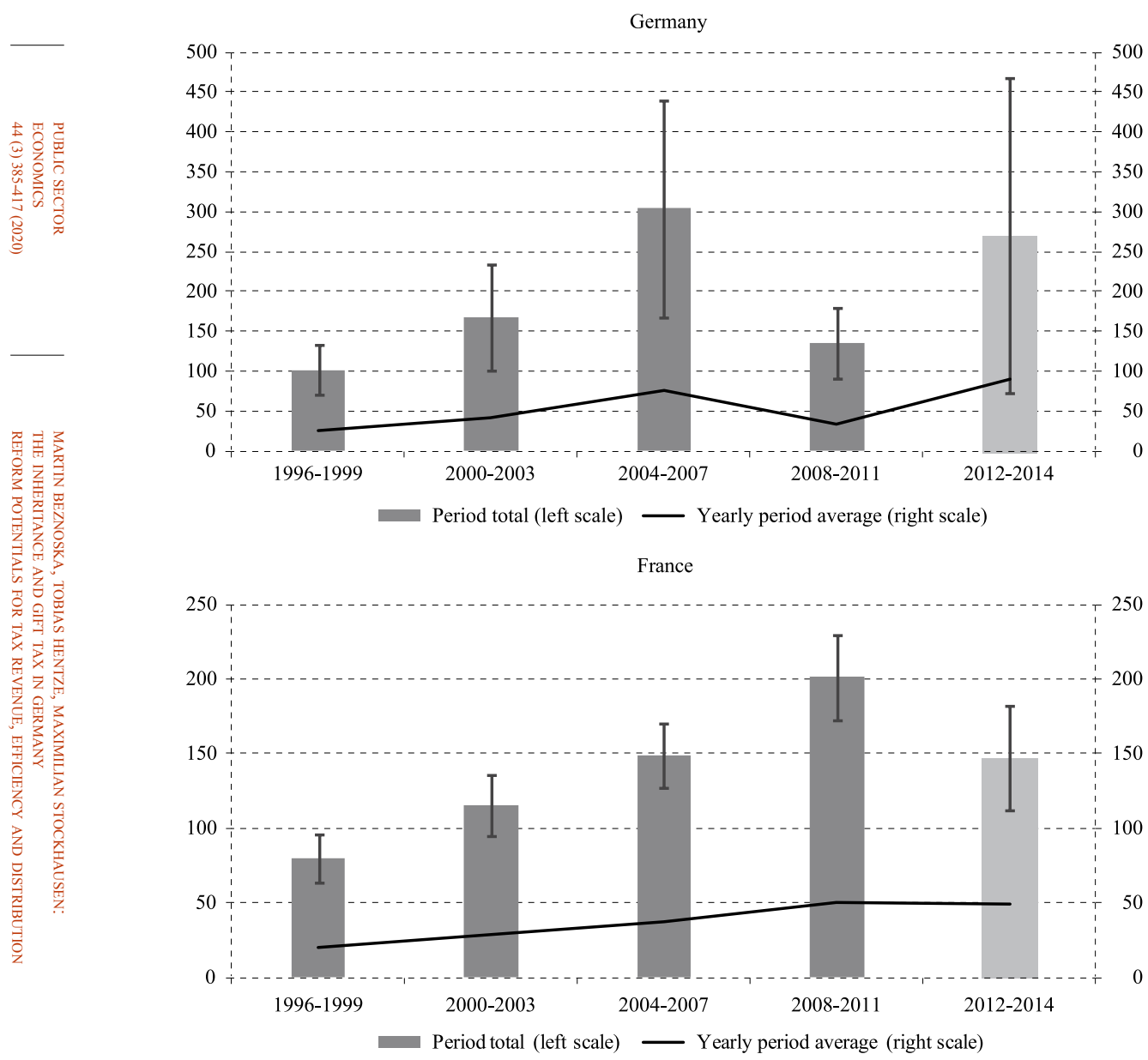

Austria

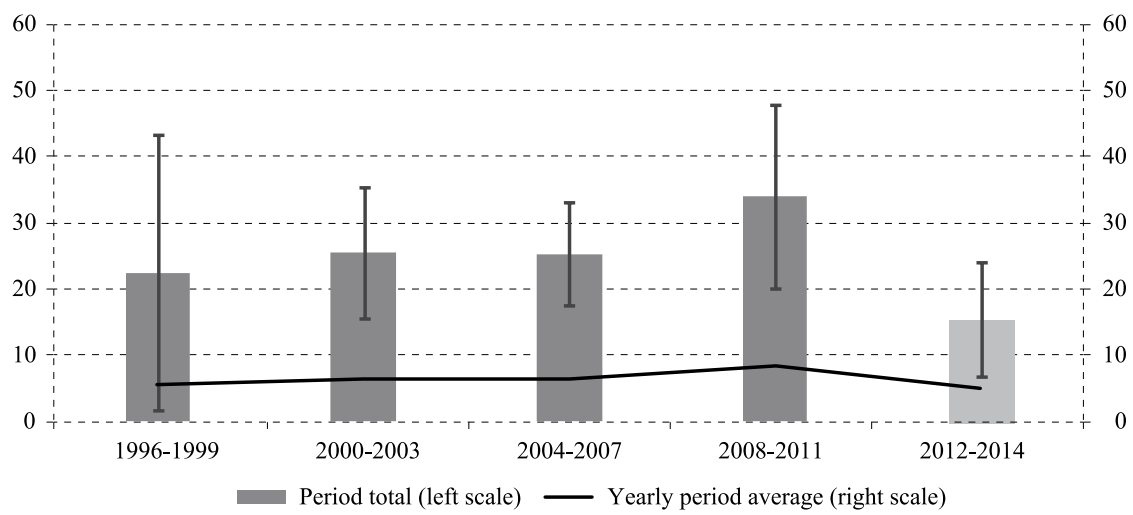

Note: In billion euro and prices of 2010. 95\% confidence intervals are calculated using multiple imputation estimates from five imputations.

Source: ECB, 2nd wave; own calculations. 
In addition, France and Germany are especially suited for the comparison because they are similar in many respects regarding, for example, population size, the GDP per capita, or the tax and transfer system. As mentioned before, the results could be distorted due to the Great Recession. However, both countries were affected in the same way, so that the direction of the distortion should be the same and the difference-in-difference estimator should not be affected much by this. In this regard, it is assumed that the higher the inheritance tax, the lower the inheritance volume. The partial increase of the inheritance tax for distant relatives in Germany should have led to a decrease in the mean volume in Germany in the years following if this effect dominates the effect from the increased allowances. This seems to be the case, as shown in Figure 4 above.

The analysis makes use of observations before and after the inheritance tax change in Germany. As before, the inheritance volume is observed over three four-year periods before and one period after the reform in Germany. The changes in France in 2008 should be of minor importance, since the HFCS only covers inheritances between different households and not intrahousehold. The fifth period (2012-2014) cannot be used because of the inheritance reform in 2012 in France which would bias the results. The treatment thus occurred in Germany in the fourth period (20082011) and the regional differences between Germany and France are exploited. Hence, Germany is the treatment group and France is the control group. The difference-in-difference estimator can be written as

$$
y_{i, t}=\beta_{0}+\beta_{1} D_{t}^{T}+\beta_{2} D_{t}^{A}+\beta_{3} D_{t}^{T} D_{t}^{A}+\beta_{4} \operatorname{agehh}_{i, t}+u_{i, t}
$$

where $y_{i, t}$ is the inheritance volume in country $i$ in period $t . D_{t}^{T}$ is a time dummy that is equal to one in all periods after the reform and otherwise zero, while $D_{t}^{A}$ is a treatment dummy, which is one only for Germany and otherwise zero. The coefficient of interest is $\beta_{3}$ since it captures the average treatment effect of the policy change, i.e. the effect of the abolition of the inheritance tax on the inheritance volume. In addition, the variable agehh controls for age effects using the age of the household head and $u_{i, t}$ is an error term.

\section{TABLE 4}

Results of the difference-in-difference estimator L4P3

\begin{tabular}{|c|c|c|c|c|c|c|}
\hline Variable & Coef. & Std. Err. & t-value & $P>t$ & \multicolumn{2}{|c|}{ [95\% Conf. Interval] } \\
\hline Time dummy $\left(\beta_{1}\right)$ & 8,482 & 5,530 & 1.53 & 0.125 & $-2,357$ & 19,322 \\
\hline Treatment dummy $\left(\beta_{2}\right)$ & 70,319 & 16,779 & 4.19 & 0.000 & 37,418 & 103,219 \\
\hline Timedy\#treatdy $\left(\beta_{3}\right)$ & $-67,325$ & 19,401 & -3.47 & 0.001 & $-105,408$ & $-29,242$ \\
\hline Age of hh head $\left(\beta_{4}\right)$ & 89 & 266 & 0.34 & 0.738 & -434 & 612 \\
\hline Constant $\left(\beta_{0}\right)$ & 61,152 & 14,536 & 4.21 & 0.000 & 32,580 & 89,724 \\
\hline Observations & 5,118 & & & & & \\
\hline
\end{tabular}

Note: Germany vs. France, period length $=4$ years each, 3 periods before treatment. Period 1: 1996-1999, period 2: 2000-2003, period 3: 2004-2007, period 4: 2008-2011. All inheritances are measured in prices of 2010. Treatment took place in Germany. Standard errors are calculated using multiple imputation estimates from five imputations.

Source: ECB, 2nd wave; own calculations. 
The results of the difference-in-difference estimation are shown in Table 4. We find evidence that the inheritance tax reform in Germany in 2008 has led to a significant decrease in the average inheritance volume. The estimated coefficient of the treatment effect $\left(\beta_{3}\right)$ is negative and statistically significant to the one percent level controlling for potential age effects. If we replace the (continuous) age variable with dummies for different age groups, the main results are not altered and households with a mid-age head tend to profit more from bequests (see Table A8 in the Appendix). Successively reducing the number of periods before the treatment does not alter the results as shown in Tables A1 and A2 in the Appendix. The treatment effect continues to be negative and statistically significant to the one and five percent level, respectively. Integrating additional time dummies for the first and second period in the baseline model to capture time effects does not change the results, either (see Table A3 in the Appendix).

In contrast, if the fifth period is included in the estimation the treatment effect vanishes. This is as expected because the inheritance tax reform in 2012 in France was like that in Germany in 2008, so that the effect points in the same direction regarding the development of the inheritance volume as in Germany. The results also change if we shift all periods to the right by one year while retaining the fouryear observation periods. This would make 2009 the first year after the reform. However, since in this case 2012 is included in the post-reform period, which is problematic in France, as mentioned, we no longer find a statistically significant effect in this case. If we shorten all the observation periods to three years so that, among other things, the period after the reform only covers the years 2009 to 2011, the resilient effect returns (see Table A4 in the Appendix). This underscores the robustness of our results.

In addition, we can show that the treatment effect also persists if only gifts are considered in the analysis. Although the sample size is smaller and the standard errors are larger, the $\mathrm{p}$-value of the estimated treatment effect $\beta_{3}$ is smaller than 0.1 , the estimator has the same negative sign as before and the scope of the effect is quite similar. Since gifts are especially important for questions of tax planning and are the main source of behavioural changes due to changes in the inheritance tax regime, they are likely to explain most of the effects we found before (see Tables A5 to A7 in the Appendix for the results).

In sum, the difference-in-difference analysis gives us empirical evidence that households directly respond to changes in inheritance taxation, for example by tax planning of donors, even if only distant relatives are affected, as was primarily the case in Germany in 2008. This is broadly in line with the results of Sommer (2017). Even though the size of the effect is hard to interpret the behavioural responses seem to be rather large. This is indicated by the large absolute and relative changes in the volume of inheritances in all three countries due to different reforms as depicted in Figure 4. 
The estimated effects from the survey data analysis of chapter 3 indicate some kinds of tax planning behaviour in response to the reform 2009. The uncertainty about the new provisions of the tax law seemed to induce pull-forward effects as well as suspensions of bequests which can appear, of course, most likely in cases of donation. Other effects would be attributed to the relocation of assets that has to occur a certain time in advance of a bequest being made. This latter source of tax base effects is hard to observe in the data. But indications for donor tax planning can be evaluated over time with the public inheritance and gift statistics (Federal Statistical Office, 2019a). However, some restrictions apply to this data.

Since inheritance cases below the threshold for personal tax allowances and thus without any tax liability do not enter the inheritance and gift statistics, the tax base named in them is substantially lower than the actual volume. Studies that estimate the annual inheritance volume for Germany put it to between 200 and 400 billion euro using information from rich-lists to correct for distortions at the top in the underlying survey data (Tiefensee and Grabka, 2017; Bach and Thiemann, 2016; Braun, 2015; Schinke, 2012; Brunner, 2014). This range shows the uncertainty of any estimates.

Regarding the observed tax base, the public inheritance and gift tax statistics distinguish between the volumes before- and after-tax exemptions for businesses. Therefore, the statistical tax base before any deductions of 84.7 billion euro for 2018 was below the actual inheritance volume. In the years 2014 to 2017 the volume was roughly 100 billion euro every year.

In 2018 , out of the remaining inheritance volume of roughly 85 billion euro, business assets of about 40 billion euro were exempted from taxation. This exempted inheritance volume reflects 20 percent of the lower bound of the estimated potential inheritance volume of 200 billion euro. Furthermore, personal tax allowances decreased the tax base by approximately 20 billion euro (equal to 10 percent of 200 billion euro). Thus, the preliminary tax base is only 13 percent of the actual inheritance volume. However, preceding inheritances. within the last 10 years before the inheritance at hand, increased the tax base in 2018 by 10 billion euro resulting in a final tax base of about 35 billion euro (which implies an average tax rate of 19 percent as the tax revenue amounts to 6.7 billion euro). The statistics refer to 194,000 inheritance cases. 


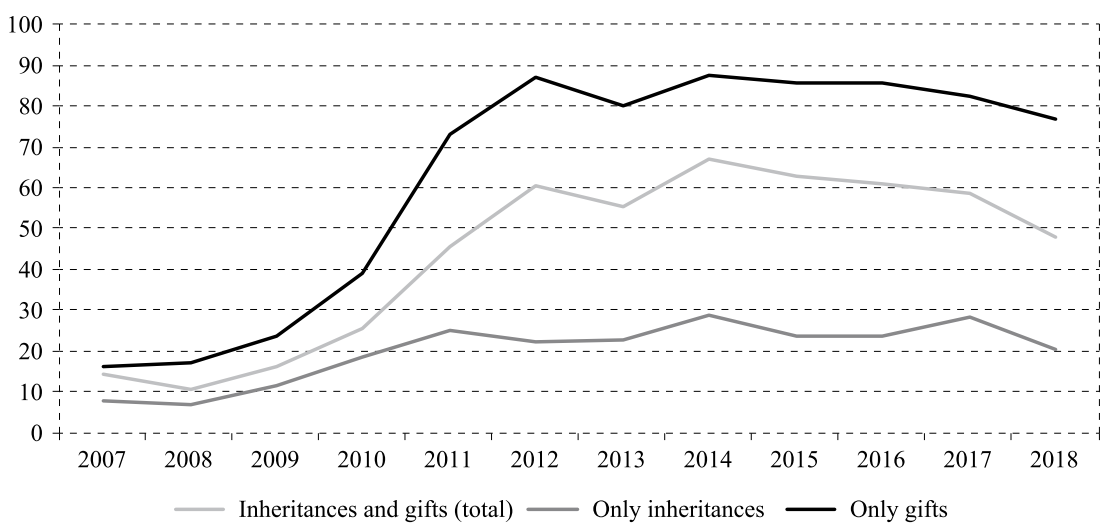

Source: Federal Statistical Office (2019a); own calculations.

Regarding the time period from 2007 to 2018, the degree of tax exemption for business assets with respect to the observed tax base (before deductions) significantly increased from 14 to 48 percent (Figure 5). This was mainly induced by the reform in 2008. However, the trend was interrupted by the recent reform in 2016. This development is in line with the general evaluation of the reforms in 2008 and 2016. Interestingly, the degree of tax exemption for business assets is much higher in terms of gifts than inheritances. This indicates that gifts are strategically used in order to benefit from the tax exemptions for business assets. In the case of death, it is, naturally, not possible to use the exemptions strategically. By transferring business assets within a family by gifts, it is possible to lower the effective tax burden. Besides this, it should be borne in mind that donors have an incentive to convert non-business assets to business assets. Interestingly, the future performance might be negatively affected by bequeathing a firm to any family member (Perez-Gonzalez, 2006).

\section{Figure 6}

Personal tax allowances divided by inheritances and gifts (in \%)

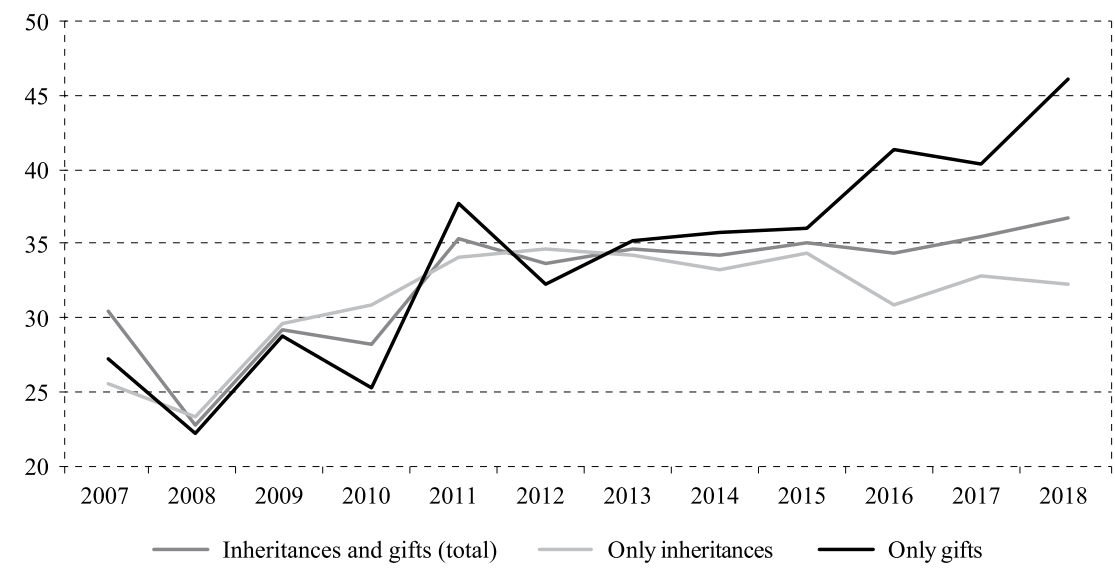

Source: Federal Statistical Office (2019a); own calculations. 
Meanwhile, personal tax allowances for family members range between 23 percent (2008) and 37 percent (2018) in terms of the total value after tax exemptions and preceding inheritances. In other words, the taxable amount is reduced by 23 and 37 percent respectively due to personal tax allowances. The gap between the percentages for inheritances and gifts is much smaller than that regarding tax exemptions for business assets. However, it has recently widened in the course of the reform in 2016. For gifts the rate was equal to 46 percent in 2018, while it was 32 percent for inheritances (Figure 6). This also indicates that gifts are strategically used in order to maximize tax allowances and, thus, to minimize the effective tax burden especially after the recent reform.

\section{Figure 7}

Average inheritance tax rate - Tax revenue divided by the final tax base (in \%)

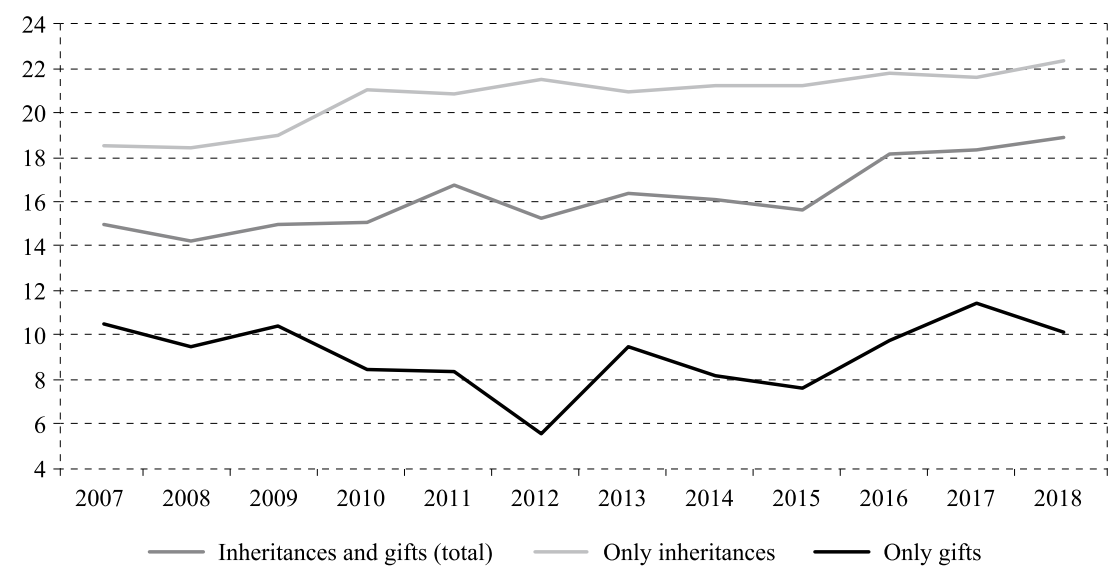

Source: Federal Statistical Office (2019a); own calculations.

The average tax rate for total inheritances and gifts, i.e. tax revenue divided by the final tax base, amounted to 19 percent in 2018 as mentioned above. The percentage has slightly fluctuated over the years which might be due to the volume of each inheritance that determines a higher or lower tax rate in accordance with the progression (Figure 7). In line with the observations in the Figures above, there is a remarkable difference between the average tax rate for inheritances and that for gifts. Again, this descriptive result supports the hypothesis that gifts are strategically used to minimize the tax burden.

While the overall average tax rate has increased in the last 10 years (Figure 7), the effective tax rate which is referred to as tax income divided by the total value before any deductions, has halved. This is due to the higher degree of tax exemptions for business assets from 2009 to 2015. In the course of the reform in 2016, the percentage has risen again since tax exemptions for business assets were restricted (Figure 8). The gap between the numbers for inheritances and gifts has remained stable over the years. 
Effective inheritance tax rate - Tax revenue divided by the total value before any deductions (in \%)

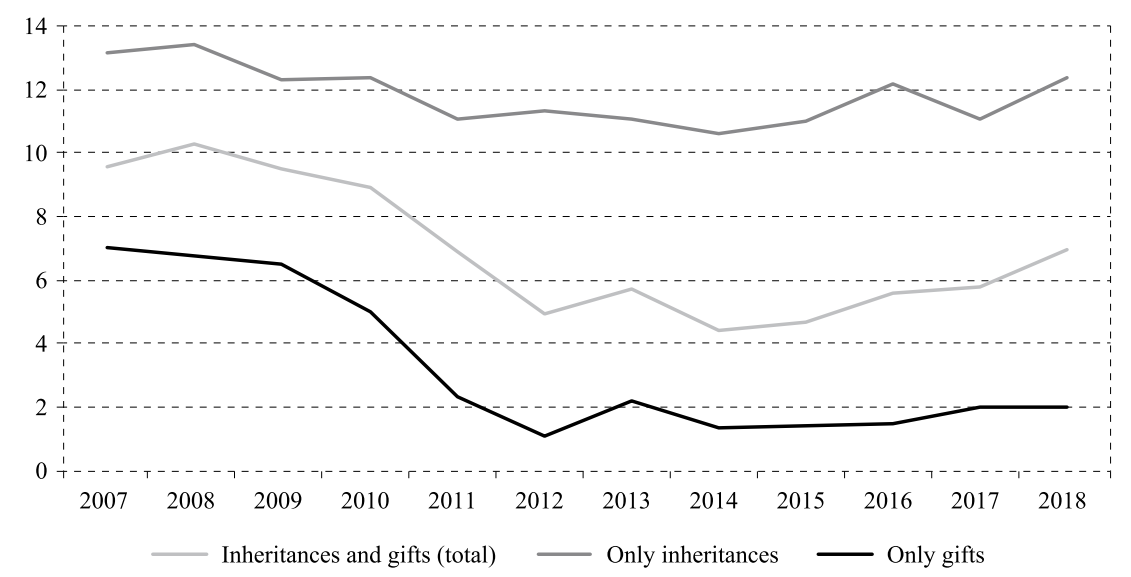

Source: Federal Statistical Office (2019a); own calculations.

\section{PROPOSALS FOR A SUSTAINABLE INHERITANCE TAX DESIGN}

In conclusion, the inheritance tax law in Germany has always been a complex issue. Efficiency losses cannot be neglected since the behavioural responses seem to be rather large. This raises the question of whether a better designed tax law could facilitate a higher degree of tax efficiency without hampering equity issues. Hence, the challenge of reforming the inheritance tax law with a high degree of efficiency and equity will be addressed.

\subsection{GENERAL REFORM OPTIONS FOR THE INHERITANCE AND GIFT TAX}

Against the background of efficiency and equity as the two fundamental principles in tax policy, a well-designed tax law is needed, to prevent negative effects on jobs and investments. An inheritance tax always means taking assets created by taxed income. Thus, it always leads to double taxation. This does not necessarily suggest neglecting the idea of inheritance taxes, rather the careful consideration of any levy to prevent distortions in economic activities. The trade-off between equity and efficiency is evident.

From an equity perspective, one could argue that high (and progressive) tax rates with rather restrictive personal tax allowances and tax exemptions would be a favourable tax design. But there are some issues that need to be addressed in this context. As already mentioned in chapter 3.1, the tax design of a high and progressive tax rate alone does not necessarily reduce wealth inequality which would depend on which and how many inheritors receive bequests. However, if there are no or only small behavioural effects, such a tax could maximize the possible revenue from inheritances and redistribute wealth among households or could improve the quality of public institutions and services. With behavioural effects, the efficiency loss would be high in such a system. The reasons for that are 
straightforward. The potential testator has a higher incentive to consume instead of saving. Most important, evasive reactions in terms of the relocation of assets can be expected to grow. It is possible to circumvent the inheritance tax by moving to another country. The data analysis in Chapter 3 gives slight evidence for these correlations, since behavioural responses to change in the inheritance tax can be observed in Germany, Austria, and France to similar extents.

Thus, from an efficiency perspective, the picture is different. A broad tax base (no exemptions for businesses and self-used real properties and rather low personal allowances), low tax rates ( 2 to 10 percent for close relatives) and extensions for payments are often recommended for a well-designed inheritance tax (SVR, 2009: 191f; Deutsches wissenschaftliches Institut der Steuerberater, 2015; Houben and Maiterth, 2011). At the same time, such a regime is at least considered not to be entirely unfair since all heirs pay their (fair) shares. Yet, extensions for tax payments are reasonable to avoid any solvency issues in the case of inherited business assets. Otherwise, a tax liability even of a rather small rate below 10 percent could cause illiquidity or the need to sell business parts or assets. In Austria, for example, the Social Democrats have proposed the reintroduction of the tax by allowing an extension for payment of 10 years (Steuerreformkommission, 2014: 191). ${ }^{1}$

There is a certain trade-off between equity and efficiency. A (low) flat tax is supposed to minimize tax avoidance and would strengthen the tax efficiency, but a progressive tax rate would lead to higher tax revenues especially regarding nonbusiness assets which are not or only slightly sensitive to tax planning. Generally, a combination of a broad tax base, i.e. no or very little exemption of business assets, and low tax rates is supposed to minimize any distortions. A reform in favour of a broad tax base and a rather low tax rate requires two substantial changes in German inheritance tax law. First, the tax exemptions for business assets must be cut. Second, personal tax allowances must be at least reduced.

Presuming a broad tax base with no exemptions, the design of the tax rates is key for the perceived equity. Today, a progressive tax rate, i.e. the (nominal) tax rates increase with the inheritance volume, is in place in Germany. Furthermore, the tax rate is higher for inheritances between unrelated parties as it decreases with the degree of relationship. Most German economists are, however, in favour of a flat tax model without any tax exemptions for the business sector (Dorn et al., 2017; Bach and Thiemann, 2016). A flat tax model would be simpler and more transparent, but it is often regarded as not fair. Such a reform - by preserving the current revenues - would result in higher tax payments for heirs of medium-sized companies, while heirs of large business assets would have to pay less than under the current system (Beznoska and Hentze, 2017). This would be the price for a transparent and understandable tax law.

\footnotetext{
${ }^{1}$ Under the current German regime, tax payments can be extended by 7 years but by applying an interest rate of 6 percent which is far too high compared to market rates. Due to the current interest policy of the European Central Bank, an interest-free deferral would be appropriate.
} 


\subsection{THE IMPLICATIONS OF A TAX SHIFT AWAY FROM LABOUR TO INHERITANCES AND GIFTS}

The tax exemptions for business assets amounted to a volume of inheritances of roughly 40 billion euro in 2018 . The average tax rate in 2018 was equal to 19 percent. Broadening the tax base and cutting the tax rate could mean taxing the additional 40 billion euro (which were exempted in reality) at a tax rate of 10 percent (instead of the actual average of 19 percent). This would lead to additional tax revenues of 4 billion euro. However, at the same time the actual tax base in 2018 would be taxed at a rate of 10 percent (instead of 19 percent) leading to a decrease in tax revenue of a little bit more than 3.2 billion euro. In other words, a reform in favour of broadening the tax base and cutting the rate would lead to only negligible additional revenues. The plus of less than 0.8 billion euro amounts to 0.1 percent of total tax revenue in Germany.

Of course, one could argue in favour of a tax rate higher than 10 percent in order to boost the revenue effect. But the extent is strongly limited as distortions are supposed to grow with the tax rate. For instance, a flat tax rate of 15 percent would lead to 4.5 billion euro additional revenues, a tax rate of 20 percent to 8.3 billion euro more (Table 5). However, this only refers to the first-round effects without any behavioural adjustments. Especially for a rather high tax rate, increasing evasion activities are likely which would shrink the revenue effect. At the same, a low flat tax rate might enlarge the tax base by reducing activities aimed at evasion.

TABle 5

Estimated revenue and labour supply effects of a flat tax reform

\begin{tabular}{llcc} 
Flat tax rate & $\mathbf{1 0}$ & $\mathbf{1 5} \%$ & $\mathbf{2 0} \%$ \\
\hline Tax revenue & \multicolumn{2}{c}{ In billion euro per year } \\
\hline Difference to status quo & 7.5 & 11.2 & 14.9 \\
\hline 0.8 & 4.5 & 8.3 \\
\hline
\end{tabular}

Estimated labor supply responses for a revenue-equivalent tax cut of the income tax

\begin{tabular}{llll}
\hline & \multicolumn{3}{c}{ In percent of total hours worked } \\
\hline Women & - & 0.10 & 0.19 \\
\hline Men & - & 0.06 & 0.11 \\
\hline
\end{tabular}

Note: Labour supply effects are evaluated at the median of the income distribution.

Source: Federal Statistical Office (2019a); GSOEP data 2018 (v34); labour supply model from Stockhausen (2019); own calculations.

The additional tax revenue can be used to flatten the progressive income tax tariff, which means to cut the marginal tax rates for a large part of the working population. In our microsimulation model (Stockhausen, 2019), such a reform can be simulated on micro data of the German Socio-Economic Panel (GSOEP) to compute labour supply effects for the population. Therefore, the second-tax bracket of the 
progressive-linear income tax tariff is smoothed to obtain a revenue-neutral reform. ${ }^{2}$ The reform lowers the marginal tax rates over a wide range of taxable income by up to 3 percentage points. However, the simulated labour supply effects are very low. Evaluated at the median of the income distribution, the shift of the tax burden from the income tax to the inheritance tax in the scenario with a flat rate of 15 percent leads to an increase of 0.1 percent of total hours worked for women. For men, the effect is even smaller with an increase of 0.06 percent. In the scenario with a 20 percent flat tax, the effects amount to 0.19 percent for women and 0.11 percent for men. Thus, the latter scenario corresponds to an increase in employment of 25,000 full-time-equivalent employed women and about 21,000 men (Federal Statistical Office, 2019b). The reason for these small effects is, on the one hand, the already high employment situation in Germany. Since women have a higher part-time employment rate, they tend to react more than men to a tax cut because of higher potentials in labour supply. In general, most of the predicted effect stems from the intensive margin. On the other hand, the additional tax revenue from the inheritance tax is just too small to allow for significant tax cuts in the income tax.

\section{Figure 9}

Distributional and labour supply effects of a cut in income tax of 8.3 billion euro (2019, in percent of gross income (tax relief) and in percent of total hours worked (labour supply)

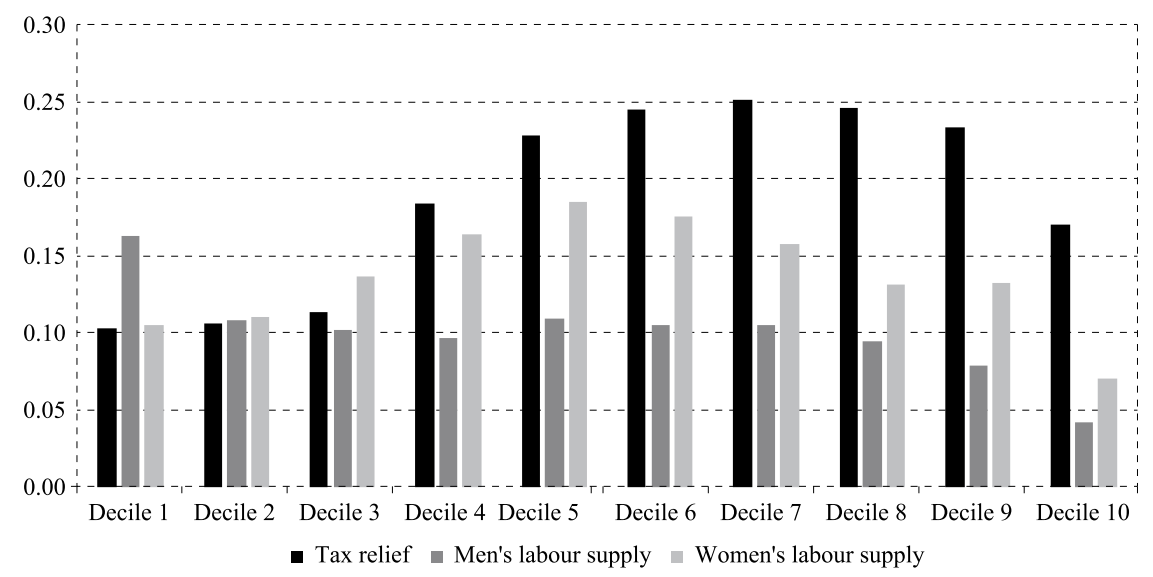

Note: Deciles of the distribution of household's equivalised gross income.

Source: GSOEP data 2018 (v34); microsimulation model Beznoska (2016); labour supply model from Stockhausen (2019); own calculations.

The distributional effects of the tax cut lie in a range between 0.1 percent and 0.25 percent of taxpayers' gross income (Figure 9). The effect increases with higher income to the seventh decile and then decreases slightly again. At the mean, this corresponds to a tax relief of about 170 euro per year per taxpayer. The highest

\footnotetext{
${ }^{2}$ This implies a shift of the beginning of the third tax-bracket according to the 2019 income tax tariff from 14,254 euro of taxable income per year to 15,400 euro ( 15 percent scenario) or 16,400 euro (20 percent scenario), respectively.
} 
labour supply responses for women are found in the middle of the income distribution. Men's labour supply effects are relatively smooth along the distribution. Exceptions are the first decile, where especially single men react more strongly, and the tenth decile with low responses in all types of households. However, the magnitudes of the effects are overall rather small.

\subsection{FURTHER REVENUE POTENTIALS OF THE INHERITANCE AND GIFT TAX}

As the potential of taxing business assets is limited in terms of increasing the tax revenue, the personal tax allowances are of special interest. From the inheritance tax statistics, it can be deduced that any inheritances which do not enter the statistics are below the respective personal tax allowance. Referring to the guestimates of the annual inheritance volume between 200 and 400 billion euro (see above), a volume of about 100 to 300 billion euro must be allocated to inheritances below the thresholds. Acknowledging the volume of 400 billion euro as appropriate, a tax rate of 10 percent would mean tax revenues of 40 billion euro. This would be a substantial increase compared to the current tax revenue of less than 7 billion euro. However, it is obvious that the main part of the additional tax revenue (32 of 33 billion euro; 1 billion euro can be allocated to taxing business assets without any tax exemptions) results from taxing small inheritances, i.e. below the personal tax allowances. Thus, increasing the revenues significantly requires, amongst other things, taxing family properties in a much broader way. Such a reform could be perceived as being unfair.

Based on Bach et al. (2014), for instance, it follows that an inheritance tax reform with a general personal tax allowance of 100,000 euro regardless of the degree of relationship, no tax exemptions for business assets and a proportional tax rate of 10 percent would lead to a revenue increase of 20 percent. Applied to the tax revenue in 2018 this would mean additional revenues of 1.4 billion euro for the price of a substantially restricted allowance volume (at least for close family members). By altering the personal tax allowances to a range between 20,000 to 200,000 euro depending on the degree of relationship the revenue increase would be about 25 percent, i.e. 1.7 billion euro with respect to 2018 . The main reason for the increase is the reduced personal tax allowance for close family members from 500,000 euro to 200,000 euro. It is more than unsure whether such a reform would be accepted by the public since most transfers of real estate would effectively constitute a tax event.

There is one restriction of this calculation, referring to gifts and not inheritances. As even rich individuals can use gifts to circumvent the inheritance tax, the cases below the personal tax allowances do not only refer to middle-class families. Therefore, the gift tax has to be interpreted as a tax privilege for rather wealthy households that can fully use the personal tax allowances several times. However, the total volume is restricted by the thresholds and the time period of 10 years in which all inheritances and gifts are cumulatively considered for tax purposes. 
In summary, the calculations reveal that not limiting exemptions for business assets, but personal allowances are key to increasing the inheritance tax revenue. However, it is more than unsure whether there will be a common approach among the political parties to tax rather small inheritances ("grandma's house"). Of course, the personal tax allowances do not have to be cut to zero but could be slightly lowered. This could increase the political support for such a reform while additional revenues could still be generated.

What lessons can be learned from this? The most striking result is that the potential of the inheritance tax to finance public needs or to lower the tax burden on labour are clearly limited unless the personal allowances are significantly cut. However, any small increase could be used to shift the tax burden from labour to wealth in terms of inheritances. Inheritance tax and income tax are correlated, as an inheritance tax can be interpreted as a tax on income of the inheritor in the sense of a net asset increase in some asset classes (windfall gains). Therefore, the inheritance tax fills a gap caused by the pattern of the income tax (Deutsches wissenschaftliches Institut der Steuerberater, 2015: 9).

From a German perspective, there are good reasons for lowering the relatively high burden on labour. The labour market suffers from rather high taxation of even low- and middle incomes. Against this background it seems plausible to shift the tax burden partly from labour to wealth since positive economic effects in terms of growth can be expected (European Commission, 2019; Altzinger and Humer, 2013).

\section{CONCLUSION AND OUTLOOK}

From a fiscal perspective, the inheritance tax has never played a major role in Germany. However, the political debate has always been intensive. Even after several reforms the German inheritance tax remains complicated. No ideas for simplification, e.g. by a flat-tax model, have been successful. The tax treatment of business assets is always subject to litigation. Therefore, an inheritance tax reform is reasonable in terms of lower assessment costs and higher tax efficiency. However, behavioural responses of private households to changes in inheritance taxation should be considered if a new inheritance law is designed. The effects of such a reform, which are mainly caused by tax planning on the part of donors and testators, can be large as shown in the difference-in-difference analysis in chapter 3. They also reflect distortions as donors make great efforts to reduce the tax burden of their heirs.

Currently, reform to broaden the tax base and cut the tax rates is often proposed. This would reduce complexity and ensure that all heirs pay their fair shares. The extent to to which gifts are used in order to minimize the tax burden could be reduced by introducing a flat tax model. Long term interest-free deferrals would be an important aspect in this regard in order to prevent any solvency issues in the case of inheritance. 
As a consequence of introducing a flat tax model with a broad tax base, the tax burden for smaller inheritances would generally increase and decrease for larger ones. This would not strengthen the equity aspect of the inheritance tax. In addition, inheritances per se do not increase wealth inequality. This depends on several preconditions, for example the position of the heir in the net wealth distribution. The importance of the inheritance tax for equity and reducing inequality is not as high as is partly presumed by politicians.

Any substantial increases in tax revenues are not likely unless the personal tax allowances are substantially cut, expanding the circle of taxpayers to those receiving smaller bequests. While increasing the tax revenue from inheritances and gifts and simultaneously lowering the tax burden on labour might increase economic efficiency, the limited revenue potential of the inheritance tax confines the possibilities of such a reform. Our simulation analysis shows that a tax shift away from labour to inheritances would increase labour supply only at a marginal level. Additionally, if inheritance tax rates are set rather high, evasion activities increase which might have a negative effect on labour demand.

In conclusion, a reform towards a flat tax model could improve tax efficiency by not hampering equity. The fiscal expectations of such a reform should not be too high as the potential to lower the tax burden on labour by increasing the inheritance tax revenue is, at least for now, rather limited.

\section{Disclosure statement}

No potential conflict of interest was reported by the authors. 
1. Altzinger, W. and Humer, S., 2013. Simulation des Aufkommens verschiedener Erbschaftsbesteuerungen. Discussion Paper. Wirtschaftsuniversität Wien.

2. Ashenfelter, O. and Card, D., 1985. Using the Longitudinal Structure of Earnings to Estimate the Effect of Training Programs. The Review of Economics and Statistics, 67(4), pp. 648-660. https://doi.org/10.2307/1924810

3. Ashenfelter, O., 1978. Estimating the Effect of Training Programs on Earnings. The Review of Economics and Statistics, 60(1), pp. 47-57.

4. Bach, S. [et al.], 2014. Aufkommens- und Verteilungswirkungen von Reformalternativen für die Erbschaft- und Schenkungsteuer. DIW Politikberatung kompakt, No. 83.

5. Bach, S. and Thiemann, A., 2016. Inheritance Tax Revenue Low Despite Surge in Inheritances. DIW Economic Bulletin, 4-5, pp. 41-48.

6. Beckert, J. and Arndt, H., R., 2016. Unverdientes Vermögen oder illegitimer Eingriff in das Eigentumsrecht? Der öffentliche Diskurs um die Erbschaftssteuer in Deutschland und Österreich. MPIfG Discussion Paper, No. 16(8).

7. Bertrand, M., Duflo, E. and Mullainathan, S., 2004. How Much Should We Trust Differences-In-Differences Estimates? The Quarterly Journal of Economics, 119(1), pp. 249-275. https://doi.org/10.1162/003355304772839588

8. Beznoska, M. and Hentze, T., 2016. Die Auswirkungen der ErbSt-Reform auf die Unternehmensnachfolge aus ökonomischer Sicht. Der Betrieb, 42, pp. 2433-2437.

9. Beznoska, M. and Hentze, T., 2017. Erbschaftsteuer: Flat-Tax-Modell schlecht für kleine Unternehmen. IW-Kurzbericht, No. 32.

10. Beznoska, M., 2016. Dokumentation zum Steuer-, Abgaben- und TransferMikrosimulationsmodell des IW Köln (STATS). IW-Report 27.

11. Beznoska, M., Niehues, J. and Stockhausen, M., 2018. Die Vermögensverteilung im internationalen Vergleich. Studie im Auftrag der vbw.

12. Bönke, T., Werder, M. and Westermeier, C., 2017. How inheritances shape wealth distributions: An international comparison. Economics Letters, 159, pp. 217-220. https://doi.org/10.1016/j.econlet.2017.08.007

13. Boserup, S. H., Kopczuk, W. and Kreiner, C. T., 2016. The Role of Bequests in Shaping Wealth Inequality: Evidence from Danish Wealth Records. American Economic Review, 106(5), pp. 656-661. https://doi.org/10.1257/aer. p20161036

14. Braun, R., 2015. Erben in Deutschland 2015-24: Volumen, Verteilung und Verwendung. Deutsches Institut für Altersvorsorge.

15. Brunner, J. K., 2014. Die Erbschaftsteuer - Bestandteil eines optimalen Steuersystems? Perspektiven der Wirtschaftspolitik, (3), pp. 199-218. https://doi. org/10.1515/pwp-2014-0019

16. Bundesministerium der Finanzen, 2019. Kassenmäßige Steuereinnahmen nach Steuerarten in den Kalenderjahren 1991 - 2018.

17. Bundesverfassungsgericht (BVerfG), 2006. Leitsätze zum Beschluss des Ersten Senats vom 7. November 2006 - 1 BvL 10/02. 
18. Card, D. and Krueger, A. B., 1994. Minimum Wages and Employment: A Case Study of the Fast-Food Industry in New Jersey and Pennsylvania. American Economic Review, 84(4), pp. 772-793. https://doi.org/10.1257/ aer.90.5.1397

19. Deutsche Bank, 2018. Erben und Vererben - Erfahrungen, Erwartungen und Pläne - eine repräsentative Studie des Instituts für Demoskopie Allensbach im Auftrag der Deutschen Bank.

20. Deutsche Bundesbank, 2019. Vermögen und Finanzen privater Haushalte in Deutschland: Ergebnisse der Vermögensbefragung 2017. Monatsbericht, April 2019, pp. 19-44.

21. Deutsches wissenschaftliches Institut der Steuerberater, 2015. Zukunft der Erbschaft- und Schenkungsteuer, Wissenschaftlicher Arbeitskreis ,,Steuerrecht “. Berlin: Institut der Steuerberater.

22. Dorn, F. [et al.], 2017. Die Erbschafsteuer in Deutschland - Reformbedarf und Reformkompromiss. ifo-Schnelldienst, 70(1), pp. 33-40.

23. ECB, 2016. The Household Finance and Consumption Survey. Results from the second wave. ECB Statistics Paper Series, 18, pp. 1-139.

24. Elinder, M., Erixson, O., Waldenström, D., 2018. Inheritance and Wealth Inequality: Evidence from Population Registers. Journal of Public Economics, 165, pp. 17-30. https://doi.org/10.1016/j.jpubeco.2018.06.012

25. European Commission, 2019. Country Report Germany 2019 - Including an In-Depth Review on the prevention and correction of macroeconomic imbalances, Commission Staff Working Document. Brussels: European Commission.

26. Federal Statistical Office, 2019a. Erbschafts- und Schenkungsteuer 2018.

27. Federal Statistical Office, 2019b. Bevölkerung und Erwerbstätigkeit - Erwerbsbeteiligung der Bevölkerung - Ergebnisse des Mikrozensus zum Arbeitsmarkt 2018, Fachserie 1 Reihe 4.1.

28. Fessler, P. and Schürz, M., 2015. Private wealth across European countries: the role of income, inheritance and the welfare state. ECB Working Paper, 1847.

29. Fessler, P., Lindner, P. and Schürz, M., 2019. Eurosystem Household Finance and Consumption Survey 2017: First results for Austria. Monetary Policy \& the Economy Q1/19.

30. Hentze, T., 2016. Eine ökonomische Analyse der Erbschaftsteuerreform. Zeitschrift für Wirtschaftspolitik, 1, pp. 1-21. https://doi.org/10.1515/zfwp2016-0006

31. Houben, H. and Maiterth, R., 2011. Erbschaftsteuer und Erbschaftsteuerreform in Deutschland: eine Bestandsaufnahme. Vierteljahrshefte zur Wirtschaftsforschung, 4, pp. 161-188. https://doi.org/10.3790/vjh.80.4.161

32. IMF, 2019. Germany - Selected Issues. IMF Country Report, No. 19/214.

33. KPMG, 2019. Cost of Capital-Newsletter.

34. Meyer, B. D., 1995. Natural and Quasi-Experiments in Economics. Journal of Business \& Economic Statistics, 13(2), pp. 151. 
35. OECD, 2018. The Role and Design of Net Wealth Taxes in the OECD. Paris: OECD. https://doi.org/10.1787/9789264290303-4-en

36. OECD, 2019. Economic Policy Reforms 2019: Going for Growth. Paris: OECD.

37. Pérez-González, F., 2006. Inherited Control and Firm Performance. American Economic Review, 5, pp. 1559-1588.

38. Piketty, T. and Saez, E., 2013. A Theory of Optimal Inheritance Taxation. Econometrica, 5, pp. 1851-1886.

39. Piketty, T., 2013. Capital in the Twenty-First Century. Cambridge: Harvard University Press.

40. Schinke, C., 2012. Inheritance in Germany 1911 to 2009: A Mortality Multiplier Approach. SOEPpapers on Multidisciplinary Panel Data Research, No. 462.

41. Schmitz, S., 2019. The Effects of Germany's Statutory Minimum Wage on Employment and Welfare Dependency. German Economic Review, 20(3), pp. 330-355. https://doi.org/10.1111/geer.12196

42. Sommer, E., 2017. Wealth Transfers and Tax Planning: Evidence for the German Bequest Tax. IZA Discussion Papers Series, No. 11120.

43. Steuerreformkommission, 2014. Bericht der Steuerreformkommission 2014.

44. Stockhausen, M., 2019. Arbeitsangebotsmodul zum IW-Mikrosimulationsmodell STATS. Dokumentation Version 1.0, IW-Report, 13.

45. SVR, 2009. Die Zukunft nicht aufs Spiel setzen. Jahresgutachten 2009/10.

46. Tiefensee, A. and Grabka, M. M., 2016. Comparing Wealth - Data Quality of the HFCS. Survey Research Methods, 10(2), pp. 119-142. https://doi. org/10.2139/ssrn.2533371

47. Tiefensee, A. and Grabka, M. M., 2017. Das Erbvolumen in Deutschland dürfte um gut ein Viertel größer sein als bisher angenommen. DIW Wochenbericht, 27, pp. 565-570.

48. Wolff, E. N. and Gittleman, M., 2014. Inheritances and the distribution of wealth or whatever happened to the great inheritance boom? Journal of Economic Inequality, 12(4), pp. 439-468. https://doi.org/10.1007/s10888-0139261-8

49. Zagheni, E. and Wagner, B., 2015. The impact of demographic change on intergenerational transfers via bequests. Demographic Research, 33(18), pp. 525-534. https://doi.org/10.4054/demres.2015.33.18 


\section{TABLE A1}

Results of the difference-in-difference estimator L4P1

Variable

Coef. Std. Err. t-value $\quad$ P>t $\quad$ [95\% Conf. Interval]

\begin{tabular}{|c|c|c|c|c|c|c|}
\hline Time dummy $\left(\beta_{1}\right)$ & 5,676 & 6,465 & 0.88 & 0.380 & $-6,994$ & 18,347 \\
\hline Treatment dummy $\left(\beta_{2}\right)$ & 95,888 & 34,141 & 2.81 & 0.005 & 28,954 & 162,822 \\
\hline Timedy\#treatdy $\left(\beta_{3}\right)$ & $-92,682$ & 37,148 & -2.49 & 0.013 & $-165,522$ & $-19,843$ \\
\hline Age of hh head $\left(\beta_{4}\right)$ & 137 & 350 & 0.39 & 0.695 & -554 & 829 \\
\hline Constant $\left(\beta_{0}\right)$ & 61,604 & 18,443 & 3.34 & 0.001 & 25,151 & 98,056 \\
\hline
\end{tabular}

Note: Germany vs. France, period length $=4$ years each, 1 period before treatment. Period 1: 2004-2007, period 2: 2008-2011. All inheritances are measured in prices of 2010. Treatment took place in Germany. Standard errors are calculated using multiple imputation estimates from five imputations.

Source: ECB, 2nd wave; own calculations.

\section{TABLE A2}

Results of the difference-in-difference estimator L $4 P 2$

\begin{tabular}{|c|c|c|c|c|c|c|}
\hline Variable & Coef. & Std. Err. & t-value & $P>t$ & \multicolumn{2}{|c|}{ [95\% Conf. Interval] } \\
\hline Time dummy $\left(\beta_{1}\right)$ & 6,604 & 5,805 & 1.14 & 0.255 & $-4,774$ & 17,982 \\
\hline Treatment dummy $\left(\beta_{2}\right)$ & 82,501 & 22,243 & 3.71 & 0.000 & 38,897 & 126,104 \\
\hline Timedy\#treatdy $\left(\beta_{3}\right)$ & $-79,983$ & 24,078 & -3.32 & 0.001 & $-127,219$ & $-32,747$ \\
\hline Age of hh head $\left(\beta_{4}\right)$ & -13 & 296 & -0.04 & 0.966 & -595 & 569 \\
\hline Constant $\left(\beta_{0}\right)$ & 68,003 & 15,983 & 4.25 & 0.000 & 36,558 & 99,449 \\
\hline Observations & 4,253 & & & & & \\
\hline
\end{tabular}

Note: Germany vs. France, period length $=4$ years each, 2 periods before treatment. Period 1: 2000-2003, period 2: 2004-2007, period 3: 2008-2011. All inheritances are measured in prices of 2010. Treatment took place in Germany. Standard errors are calculated using multiple imputation estimates from five imputations.

Source: ECB, 2nd wave; own calculations. 


\section{TABLE A3}

Results of the difference-in-difference estimator with additional period dummies L4P3

Variable

Time dummy $\left(\beta_{1}\right)$

Treatment dummy $\left(\beta_{2}\right)$

Timedy\#treatdy $\left(\beta_{3}\right)$

Age of hh head $\left(\beta_{4}\right)$

Period 1 dummy

Period 2 dummy

Constant $\left(\beta_{0}\right)$

Observations

Coef. Std. Err. t-value $\mathbf{P}>\mathbf{t} \quad \mathbf{9 5 \%} \%$ Conf. Interval]

\begin{tabular}{|c|c|c|c|c|c|}
\hline$-6,040$ & 11,301 & -0.53 & 0.593 & $-28,189$ & 16,110 \\
\hline 70,439 & 16,771 & 4.20 & 0.000 & 37,553 & 103,324 \\
\hline$-67,024$ & 19,166 & -3.50 & 0.000 & $-104,646$ & $-29,402$ \\
\hline 180 & 247 & 0.73 & 0.467 & -307 & 668 \\
\hline$-36,169$ & 16,847 & -2.15 & 0.032 & $-69,193$ & $-3,146$ \\
\hline$-17,868$ & 18,519 & -0.96 & 0.335 & $-54,169$ & 18,434 \\
\hline 71,233 & 18,056 & 3.95 & 0.000 & 35,821 & 106,646 \\
\hline
\end{tabular}

Note: Germany vs. France, period length $=4$ years each, 3 periods before treatment. Period 1: 1996-1999, period 2: 2000-2003, period 3: 2004-2007, period 4: 2008-2011. All inheritances are measured in prices of 2010. Treatment took place in Germany. Standard errors are calculated using multiple imputation estimates from five imputations.

Source: ECB, 2nd wave; own calculations.

\section{TABLE A4}

Results of the difference-in-difference estimator L3P4

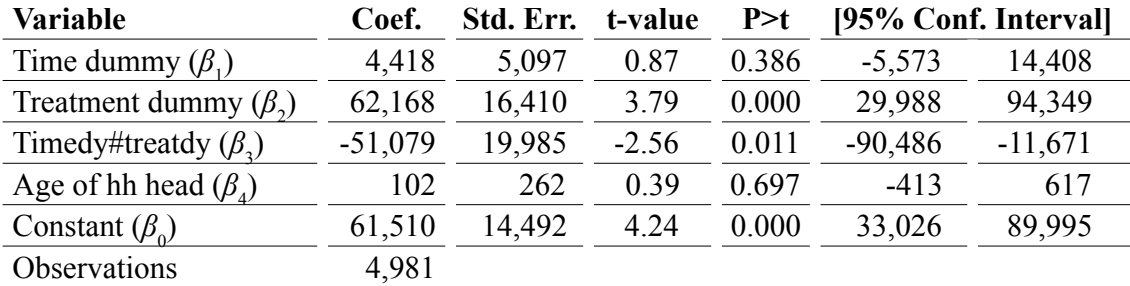

Note: Germany vs. France, period length $=3$ years each, 4 periods before treatment. Period 1: 1997-1999, period 2: 2000-2002, period 3: 2003-2005, period 4: 2006-2008, period 5: 20092011. All inheritances are measured in prices of 2010. Treatment took place in Germany. Standard errors are calculated using multiple imputation estimates from five imputations.

Source: ECB, 2nd wave; own calculations. 


\section{TABLE A5}

Results of the difference-in-difference estimator using gifts only $L 4 P 3 G$

Variable

Coef. Std. Err. t-value $\quad \mathbf{P}>\mathbf{t} \quad$ [95\% Conf. Interval]

\begin{tabular}{|c|c|c|c|c|c|c|}
\hline Time dummy $\left(\beta_{1}\right)$ & $-2,392$ & 7,905 & -0.30 & 0.762 & $-17,887$ & 13,102 \\
\hline Treatment dummy $\left(\beta_{2}\right)$ & 73,343 & 35,500 & 2.07 & 0.039 & 3,764 & 142,923 \\
\hline Timedy\#treatdy $\left(\beta_{3}\right)$ & $-76,710$ & 40,648 & -1.89 & 0.059 & $-156,395$ & 2,975 \\
\hline Age of hh head $\left(\beta_{4}\right)$ & 929 & 497 & 1.87 & 0.062 & -45 & 1,903 \\
\hline Constant $\left(\beta_{0}\right)$ & 33,968 & 23,540 & 1.44 & 0.149 & $-12,181$ & 80,118 \\
\hline
\end{tabular}

Note: Germany vs. France, period length $=4$ years each, 3 periods before treatment. Period 1: 1996-1999, period 2: 2000-2003, period 3: 2004-2007, period 4: 2008-2011. All inheritances are measured in prices of 2010. Treatment took place in Germany. Standard errors are calculated using multiple imputation estimates from five imputations.

Source: ECB, 2nd wave; own calculations.

\section{TABLE A6}

Results of the difference-in-difference estimator using gifts only $L 4 P 2 G$

\begin{tabular}{|c|c|c|c|c|c|c|}
\hline Variable & Coef. & Std. Err. & t-value & $P>t$ & \multicolumn{2}{|c|}{ [95\% Conf. Interval] } \\
\hline Time dummy $\left(\beta_{1}\right)$ & $-5,691$ & 8,114 & -0.70 & 0.483 & $-21,594$ & 10,212 \\
\hline Treatment dummy $\left(\beta_{2}\right)$ & 98,578 & 51,256 & 1.92 & 0.054 & $-1,882$ & 199,039 \\
\hline Timedy\#treatdy $\left(\beta_{3}\right)$ & $-101,722$ & 56,015 & -1.82 & 0.069 & $-211,519$ & 8,075 \\
\hline Age of hh head $\left(\beta_{4}\right)$ & 969 & 577 & 1.68 & 0.093 & -162 & 2,099 \\
\hline Constant $\left(\beta_{0}\right)$ & 35,655 & 26,692 & 1.34 & 0.182 & $-16,697$ & 88,007 \\
\hline Observations & 1,585 & & & & & \\
\hline
\end{tabular}

Note: Germany vs. France, period length $=4$ years each, 2 periods before treatment. Period 1: 2000-2003, period 2: 2004-2007, period 3: 2008-2011. All inheritances are measured in prices of 2010. Treatment took place in Germany. Standard errors are calculated using multiple imputation estimates from five imputations.

Source: ECB, 2nd wave; own calculations. 
TABLE A7

Results of the difference-in-difference estimator with additional period dummies using gifts only $L 4 P 3 G$

\begin{tabular}{|c|c|c|c|c|c|c|}
\hline Variable & Coef. & Std. Err. & t-value & $P>t$ & \multicolumn{2}{|c|}{ [95\% Conf. Interval] } \\
\hline Time dummy $\left(\beta_{1}\right)$ & $-29,450$ & 21,293 & -1.38 & 0.167 & $-71,184$ & 12,284 \\
\hline Treatment dummy $\left(\beta_{2}\right)$ & 77,108 & 37,865 & 2.04 & 0.042 & 2,893 & 151,322 \\
\hline Timedy\#treatdy $\left(\beta_{3}\right)$ & $-78,869$ & 41,919 & -1.88 & 0.060 & $-161,042$ & 3,305 \\
\hline Age of hh head $\left(\beta_{4}\right)$ & 1,210 & 452 & 2.68 & 0.008 & 323 & 2,097 \\
\hline Period 1 dummy & $-70,068$ & 40,394 & -1.73 & 0.083 & $-149,239$ & 9,102 \\
\hline Period 2 dummy & $-28,646$ & 38,051 & -1.02 & 0.310 & $-113,223$ & 35,932 \\
\hline Constant $\left(\beta_{0}\right)$ & 49,616 & 29,682 & 1.67 & 0.095 & $-8,569$ & 107,801 \\
\hline Observations & 1,906 & & & & & \\
\hline
\end{tabular}

Note: Germany vs. France, period length $=4$ years each, 3 periods before treatment. Period 1: 1996-1999, period 2: 2000-2003, period 3: 2004-2007, period 4: 2008-2011. All inheritances are measured in prices of 2010. Treatment took place in Germany. Standard errors are calculated using multiple imputation estimates from five imputations.

Source: ECB, 2nd wave; own calculations.

\section{TABLE A8}

Results of the difference-in-difference estimator with additional period dummies and age group dummies $L 4 P 3 A G$

\begin{tabular}{|c|c|c|c|c|c|c|}
\hline Variable & Coef. & Std. Err. & t-value & $P>t$ & \multicolumn{2}{|c|}{ [95\% Conf. Interval] } \\
\hline Time dummy $\left(\beta_{1}\right)$ & $-3,970$ & 10,892 & -0.36 & 0.715 & $-25,318$ & 17,378 \\
\hline Treatment dummy $\left(\beta_{2}\right)$ & 71,151 & 17,373 & 4.10 & $\overline{0.000}$ & 37,082 & 105,220 \\
\hline Timedy\#treatdy $\left(\beta_{3}\right)$ & $-64,576$ & 19,262 & -3.35 & $\overline{0.001}$ & $-102,388$ & $-26,765$ \\
\hline Period 1 dummy & $-34,731$ & 15,962 & -2.18 & 0.030 & $-66,020$ & $-3,441$ \\
\hline Period 2 dummy & $-15,400$ & 18,045 & -0.85 & 0.393 & $-50,773$ & 19,973 \\
\hline \multicolumn{7}{|l|}{$\begin{array}{l}\text { Age groups (ref:: } \\
16-30)\end{array}$} \\
\hline Age 31-45 & 59,955 & 21,593 & 2.78 & 0.006 & 17,527 & 102,383 \\
\hline Age 46-60 & 57,262 & 15,970 & 3.59 & 0.000 & 25,845 & 88,680 \\
\hline Age 61-75 & 42,944 & 14,381 & 2.99 & $\overline{0.004}$ & 14,185 & 71,702 \\
\hline Age $76+$ & 39,859 & 16,015 & 2.49 & 0.013 & 8,401 & 71,318 \\
\hline Constant $\left(\beta_{0}\right)$ & 29,656 & 14,614 & 2.03 & 0.043 & 933 & 58,379 \\
\hline Observations & 5,118 & & & & & \\
\hline
\end{tabular}

Source: ECB, 2nd wave; own calculations. 